Article

\title{
Effects of Alkaline Pre-Etching to Metal Hydride Alloys
}

\author{
Tiejun Meng ${ }^{1}$, Kwo-Hsiung Young ${ }^{1,2, *}$ (D), Chaolan $\mathrm{Hu}^{1}$ and Benjamin Reichman ${ }^{1}$ \\ 1 BASF/Battery Materials-Ovonic, 2983 Waterview Drive, Rochester Hills, MI 48309, USA; \\ pkumeng@hotmail.com (T.M.); sherry.hu@basf.com (C.H.); Benjamin.reichman@basf.com (B.R.) \\ 2 Department of Chemical Engineering and Materials Science, Wayne State University, Detroit, MI 48202, USA \\ * Correspondence: kwo.young@basf.com; Tel.: +1-248-293-7000
}

Received: 10 September 2017; Accepted: 29 September 2017; Published: 5 October 2017

\begin{abstract}
The responses of one $\mathrm{AB}_{5}$, two $\mathrm{AB}_{2}$, four $\mathrm{A}_{2} \mathrm{~B}_{7}$, and one $\mathrm{C} 14$-related body-centered-cubic (BCC) metal hydrides to an alkaline-etch $\left(45 \% \mathrm{KOH}\right.$ at $110{ }^{\circ} \mathrm{C}$ for $\left.2 \mathrm{~h}\right)$ were studied by internal resistance, $\mathrm{X}$-ray diffraction, scanning electron microscope, inductively coupled plasma, and AC impedance measurements. Results show that while the etched rare earth-based $A_{5}$ and $A_{2} B_{7}$ alloys surfaces are covered with hydroxide/oxide (weight gain), the transition metal-based $\mathrm{AB}_{2}$ and BCC-C14 alloys surfaces are corroded and leach into electrolyte (weight loss). The C14-predominated $\mathrm{AB}_{2}$, La-only $\mathrm{A}_{2} \mathrm{~B}_{7}$, and Sm-based $\mathrm{A}_{2} \mathrm{~B}_{7}$ showed the most reduction in the internal resistance with the alkaline-etch process. Etched $A_{2} B_{7}$ alloys with high La-contents exhibited the lowest internal resistance and are suggested for use in the high-power application of nickel/metal hydride batteries.
\end{abstract}

Keywords: metal hydride alloy; nickel metal hydride battery; alkaline bath; high rate performance; superlattice alloys; surface morphology

\section{Introduction}

Metal hydride (MH) alloy, or hydrogen storage alloy, is a group of intermetallic alloys (IMCs) capable of storing hydrogen in the solid form [1]. One of its key applications is the rechargeable nickel/metal hydride (Ni/MH) battery, which is used widely in consumer electronics, as well as stationary and transportation energy storage areas. A large variety of IMCs have been used/proposed as the active materials in the negative electrode of $\mathrm{Ni} / \mathrm{MH}$ battery, such as $\mathrm{A}_{2} \mathrm{~B}[2], \mathrm{AB}[3,4], \mathrm{AB}_{2}[5]$, $\mathrm{AB}_{3}$ [6], $\mathrm{A}_{2} \mathrm{~B}_{7}$ [7], $\mathrm{A}_{5} \mathrm{~B}_{19}$ [8], $\mathrm{AB}_{5}$ [9], body-centered-cubic (BCC) solid solution [10], and their combinations [11,12]. These IMCs are composed of mostly transition metals (TM), and some may contain rare-earth (RE) elements. The electrochemical high-rate performances of some of these $\mathrm{MH}$ alloys were compared in 2010 and the RE-based $\mathrm{AB}_{5} \mathrm{MH}$ alloy had the best high-rate dischargeability (HRD) performance [13]. The magnetic susceptibilities of these alloys, and a couple new ones, were compared in a 2013 article [14]. With several new MH alloys, especially the recently discovered superlattice $A_{2} B_{7}$-based ones with improved electrochemical properties, it is important to update the comparison results.

A few pre-activation processes, such as surface fluorination, alkaline bath, acid etch, mechanical alloying, etc., were proposed to shorten the activation process and improve the electrochemical performance of the $\mathrm{MH}$ alloys (see a review in [15]). Among these processes, the alkaline bath is very effective in dissolving the native oxide, so as to form a porous oxide surface with catalytic $\mathrm{Ni}$ clusters imbedded [13,16-22] and to increase the surface reactive area [23]. In the past, we have used this technique to prepare the alloy for the study of activated surfaces without going through electrochemical formation cycling [24]. 


\section{Experimental Set-Up}

MH alloys were prepared by either vacuum induction melting (VIM) or arc melting (AM). Details of the melting process were reported before $[25,26]$. The main difference between these two preparation methods is the size of ingot. While the former is usually used in large production (1-1000 kg), the latter is mostly used in laboratories (5-200 g) [15]. Some alloys went through annealing either in vacuum or Ar. The obtained ingot was hydrided first, followed by grinding and sifting into a -200 mesh size powder. To make the electrode, the powder was compacted directly onto a $1 \mathrm{~cm} \times 1 \mathrm{~cm}$ expanded Ni substrate without any binder or conductive metal powder. The loading of powder per electrode ranged from 70 to $100 \mathrm{mg}$. The $\mathrm{KOH}$ etching (activation) experiment was performed on the electrode assembly in $45 \mathrm{wt} \% \mathrm{KOH}$ at $110{ }^{\circ} \mathrm{C}$ for $2 \mathrm{~h}$. After the etching process, the electrode was pulled out, rinsed by deionized water, dried, and tested. A Suzuki-Shokan multi-channel pressure-concentration-temperature system (PCT, Suzuki Shokan, Tokyo, Japan) was used to measure the MH-hydrogen interaction in gaseous phase. PCT measurements at various temperatures were performed after activation, which consisted of a $2 \mathrm{~h}$ thermal cycle between room temperature and $300{ }^{\circ} \mathrm{C}$ under $2.5 \mathrm{MPa} \mathrm{H}_{2}$ pressure. A Varian Liberty 100 inductively coupled plasma optical emission spectrometer (ICP-OES, Agilent Technologies, Santa Clara, CA, USA) was used to study the chemical composition of the solution after etching. A Philips X'Pert Pro X-ray diffractometer (XRD, Philips, Amsterdam, The Netherlands) was used to perform the phase analysis, and a JEOL-JSM6320F scanning electron microscope (SEM, JEOL, Tokyo, Japan) was also used to investigate the phase distribution and composition.

A $30 \mathrm{wt} \% \mathrm{KOH}$ electrolyte, a $\mathrm{Hg} / \mathrm{HgO}$ reference electrode, and a sintered $\mathrm{Ni}(\mathrm{OH})_{2} / \mathrm{NiOOH}$ counter electrode were used for the electrochemical testing. The internal resistance measurement was performed in the following steps:

(1) Charge at $0.1 \mathrm{C}$ and discharge at $0.1 \mathrm{C}$ (to $-0.7 \mathrm{~V}$ vs. $\mathrm{Hg} / \mathrm{HgO}$ ). Record discharge capacity;

(2) Charge at $0.1 \mathrm{C}$, discharge $0.1 \mathrm{C}$ to $80 \%$ state-of-charge (SOC);

(3) Conduct internal resistance test at $80 \%$ SOC (1st internal resistance test):

a. Put in open circuit for $10 \mathrm{~min}$;

b. Discharge at $0.5 \mathrm{C}$ for $10 \mathrm{~s}$;

c. Charge at $0.5 \mathrm{C}$ for $10 \mathrm{~s}$;

d. Put in open circuit for $10 \mathrm{~min}$;

e. Discharge at $2 \mathrm{C}$ for $10 \mathrm{~s}$;

f. Charge at $2 \mathrm{C}$ for $10 \mathrm{~s}$;

g. Put in open circuit for $10 \mathrm{~min}$;

h. Calculate internal resistance.

(4) Charge at $0.1 \mathrm{C}$ back from $80 \%$ SOC to $100 \%$ SOC;

(5) Conduct 4 more capacity tests at $0.2 \mathrm{C}$ charge rate and $0.1 \mathrm{C}$ discharge rate. Record discharge capacities;

(6) Repeat step 3 (2nd internal resistance test);

(7) Repeat step 4;

(8) Conduct rate test:
a. Charge at $0.2 \mathrm{C}$, discharge at $0.1 \mathrm{C}$;
b. Charge at $0.2 \mathrm{C}$, discharge at $0.2 \mathrm{C}$;
c. Charge at $0.2 \mathrm{C}$, discharge at $0.5 \mathrm{C}$;
d. Charge at $0.2 \mathrm{C}$, discharge at $1 \mathrm{C}$;
e. Charge at $0.2 \mathrm{C}$, discharge at $2 \mathrm{C}$;
f. Charge at $0.2 \mathrm{C}$, discharge at $3 \mathrm{C}$; 
g. Charge at $0.2 \mathrm{C}$, discharge at $5 \mathrm{C}$.

(9) Repeat step 3 (3rd internal resistance test).

A Solartron 1250 Frequency Response Analyzer (Solartron Analytical, Leicester, UK) with a sine wave amplitude of $10 \mathrm{mV}$ and a frequency range of $0.5 \mathrm{mHz}$ to $10 \mathrm{kHz}$ was used for the alternative current $(\mathrm{AC})$ impedance measurements.

\section{Results and Discussions}

\subsection{Alloys Selection}

Eight MH alloys (A-H) were selected for this study. The composition and preparation method of each alloy are summarized in Table 1. Details in microstructures of these alloys can be found in the cited reference at the last column in Table 1 . A is the most commonly used RE-based $\mathrm{AB}_{5}$ alloy in the $\mathrm{Ni} / \mathrm{MH}$ battery. $\mathbf{B}$ and $\mathbf{C}$ are TM-based $\mathrm{AB}_{2}$ alloys with dominating $\mathrm{C} 14$ and $\mathrm{C} 15$ structures, respectively. $\mathbf{D}$ is a Laves-phase related BCC solid solution $\mathrm{MH}$ alloy composed of a main BCC phase and C14 and TiNi secondary phases, and shows a high capacity at a moderate rate that is suitable for electric vehicle application [12]. Alloys E-H are RE-and $\mathrm{Mg}$-containing $\mathrm{A}_{2} \mathrm{~B}_{7}$-based superlattice alloys used mainly in the high-performance consumer $\mathrm{Ni} / \mathrm{MH}$ batteries $[7,27,28]$. PCT isotherms measured at $30{ }^{\circ} \mathrm{C}$ and room temperature half-cell discharge capacities in the first 10 electrochemical cycles for eights alloys in this study are compared in Figures 1 and 2, respectively. The capacities of these alloys are summarized in Table 1 . The BCC-C14 alloy (D) has the highest hydrogen-storage capacity whereas $C 14 A_{2}$ alloys $(B)$, and superlattice alloys $(\mathbf{E}, \mathbf{G}$, and $\mathbf{H})$ are next, followed by the standard $A_{5}$ alloy (A). The half-cell discharge capacity of $C 15 A_{2}$ alloy $(C)$ is the lowest due to its relatively high hydrogen equilibrium pressure, which makes it difficult to charge into higher state-of-charge in the open-air environment. Alloy $\mathrm{F}$ has the lowest discharge capacity in the superlattice alloy family (E-H) because of its high Sm-content. From Figure 2, the ease of activation in order is E, F, G $>$ C, H $>$ A > D, B. In general, Mg-containing superlattice alloys are easier to activate, and alloys without $\mathrm{La}(\mathbf{B}, \mathbf{D})$ take more cycles to reach their maximum capacities. The addition of rare elements to a TM-based $\mathrm{MH}$ alloy to improve the activation behavior is a well-known recipe for the preparation of electrochemical applications [29-36].

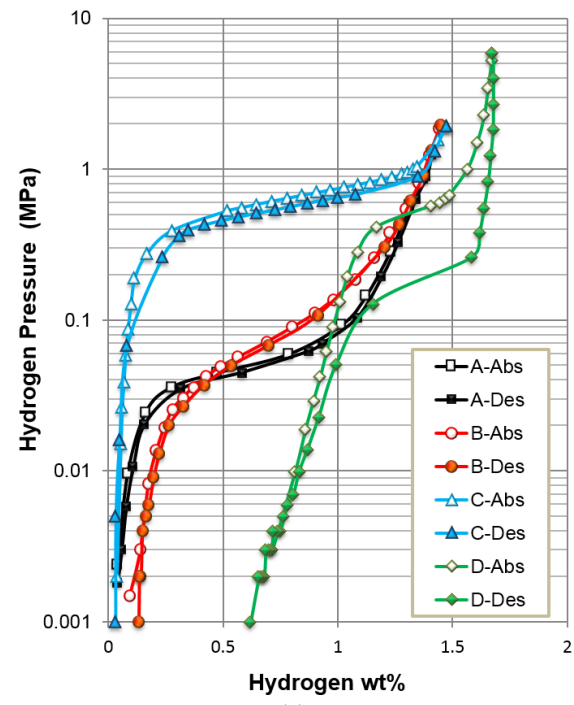

(a)

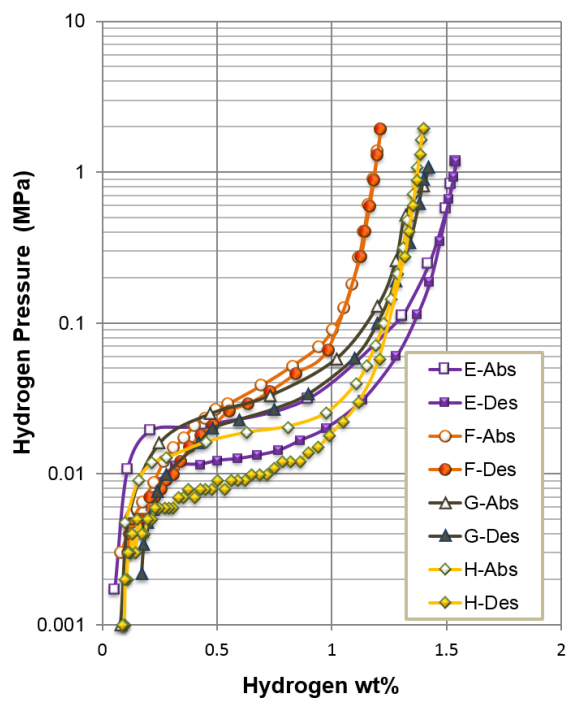

(b)

Figure 1. Pressure-concentration-temperature system (PCT) isotherms measured at $30^{\circ} \mathrm{C}$ for as-is alloys (a) A-D and (b) E-H. Open and solid symbols represent the absorption and desorption curves, respectively. 


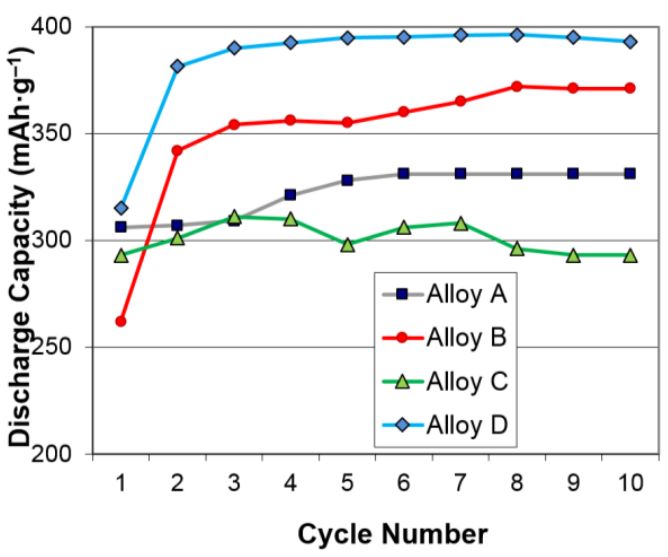

(a)

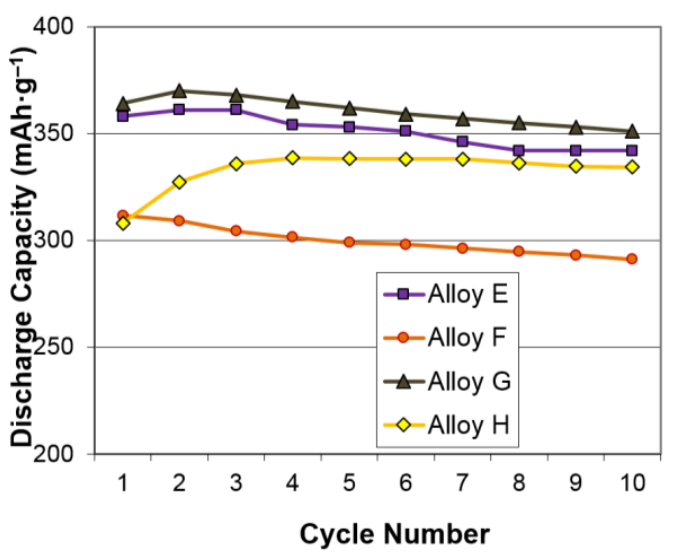

(b)

Figure 2. Electrochemical full-capacity activation behavior for as-is alloys (a) A-D and (b) E-H.

Table 1. Preparation and properties of alloys used in this study. Low-rate discharge capacity and saturated magnetic susceptibility $\left(M_{\mathrm{S}}\right)$ are in the units of $\mathrm{mAh} \cdot \mathrm{g}^{-1}$ and $\mathrm{emu} \cdot \mathrm{g}^{-1}$, respectively. HRDs are the ratio of capacities between 50 and $4 \mathrm{~mA} \cdot \mathrm{g}^{-1}$ for B-D and capacities between 100 and $8 \mathrm{~mA} \cdot \mathrm{g}^{-1}$ for all other alloys.

\begin{tabular}{|c|c|c|c|c|c|c|c|c|}
\hline Alloys & System & Composition & Melting & Annealing & Capacity & HRD & $M_{\mathrm{S}}$ & Reference \\
\hline $\mathbf{A}$ & $\mathrm{AB}_{5}$ & $\begin{array}{c}\mathrm{La}_{10.5} \mathrm{Ce}_{4.3} \mathrm{Pr}_{0.5} \mathrm{Nd}_{1.4} \mathrm{Ni}_{60} \\
\mathrm{Co}_{12.7} \mathrm{Mn}_{5.9} \mathrm{Al}_{4.7}\end{array}$ & VIM & $\begin{array}{c}\text { In } \\
\text { vacuum }\end{array}$ & 331 & 0.99 & 0.43 & A in [13] \\
\hline B & $\mathrm{AB}_{2}-\mathrm{C} 14$ & $\begin{array}{l}\mathrm{Zr}_{21.5} \mathrm{Ti}_{12} \mathrm{~V}_{310} \mathrm{Cr}_{7.5} \mathrm{Mn}_{8.1} \\
\mathrm{Co}_{8} \mathrm{Ni}_{32.2} \mathrm{Sn}_{0.3} \mathrm{Al}_{0.4}\end{array}$ & VIM & None & 354 & 0.90 & 0.04 & $\mathrm{Mo} 0$ in [37] \\
\hline $\mathrm{C}$ & $\mathrm{AB}_{2}-\mathrm{C} 15$ & $\begin{array}{c}\mathrm{Zr}_{25} \mathrm{Ti}_{6.5} \mathrm{~V}_{3.9} \mathrm{Mn}_{22.2} \mathrm{Fe}_{3.8} \\
\mathrm{Ni}_{38} \mathrm{Sn}_{0.3} \mathrm{La}_{0.3}\end{array}$ & $\mathrm{AM}$ & None & 307 & 0.99 & 0.04 & C15 in [38] \\
\hline D & BCC-C14 & $\begin{array}{c}\mathrm{Zr}_{2.1} \mathrm{Ti}_{15.6} \mathrm{~V}_{44} \mathrm{Cr}_{11.2} \mathrm{Mn}_{6.9} \\
\mathrm{Co}_{1.4} \mathrm{Ni}_{18.5} \mathrm{Al}_{0.3}\end{array}$ & VIM & None & 397 & 0.95 & 0.39 & P17 in [39] \\
\hline E & $\mathrm{A}_{2} \mathrm{~B}_{7}$ & $\mathrm{La}_{16.3} \mathrm{Mg}_{7} \mathrm{Ni}_{65.1} \mathrm{Co}_{11.6}$ & VIM & In $\mathrm{Ar}$ & 361 & 0.98 & 0.37 & $C$ in [13] \\
\hline $\mathbf{F}$ & $\mathrm{A}_{2} \mathrm{~B}_{7}$ & $\mathrm{La}_{6} \mathrm{Sm}_{13.8} \mathrm{Mg}_{3} \mathrm{Ni}_{73.8} \mathrm{Al}_{3.4}$ & VIM & In $\mathrm{Ar}$ & 320 & 0.99 & 0.60 & A3 in [40] \\
\hline G & $\mathrm{A}_{2} \mathrm{~B}_{7}$ & $\begin{array}{c}\mathrm{La}_{11.3} \operatorname{Pr}_{1.7} \mathrm{Nd}_{5.1} \mathrm{Mg}_{4.5} \mathrm{Ni}_{63.6} \\
\mathrm{Co}_{13.6} \mathrm{Zr}_{0.2}\end{array}$ & VIM & In $\mathrm{Ar}$ & 370 & 0.98 & 1.19 & $\mathrm{~B}$ in $[41]$ \\
\hline $\mathbf{H}$ & $\mathrm{A}_{2} \mathrm{~B}_{7}$ & $\begin{array}{c}\mathrm{La}_{3.9} \mathrm{Pr}_{7.7} \mathrm{Nd}_{7.7} \mathrm{Mg}_{3.9} \mathrm{Ni}_{68.1} \\
\mathrm{Co}_{4.7} \mathrm{Al}_{4}\end{array}$ & VIM & In $\mathrm{Ar}$ & 354 & 0.94 & 0.62 & $\mathrm{C} 3$ in [42] \\
\hline
\end{tabular}

\subsection{Electrochemical Results}

Four electrodes from each alloy went through half-cell electrochemical testing. Examples of capacities measured at different rates and three internal resistances $(R)$ from alloy $\mathbf{A}$ (as-is), alloy $\mathbf{B}$ (as-is and etched), and alloy E (as-is and etched) are plotted in Figures 3 and 4. The voltage dropped very quickly with the increase in the discharge current, which resulted in a significant decrease in measured capacity. The etched $\mathrm{C} 14 \mathrm{AB}_{2}$ alloy $(\mathbf{B})$ shows the highest discharge capacity, up to a $2 \mathrm{C}$ rate. In the comparison of $R$, the etched $\mathrm{E}$ shows the lowest resistance, and, in general, the HRD capability is in the order of $A_{2} B_{7}(E)>A_{5}(A)>A B_{2}(B)$ regardless of being etched. This finding is consistent with our previous reports $[40,43]$.

The electrochemical testing results are summarized in Table 2. The reported capacity and internal resistance are highest when obtained with a $0.1 \mathrm{C}$ discharge rate and the lowest value in the three measurements, respectively. The specific power $(P)$ was estimated by using formula:

$$
P=2\left(0.45-V_{\mathrm{oc}}\right)^{2} / 9 R
$$

where 0.45 and $V_{\mathrm{oc}}$ are the voltage of $\mathrm{Ni}(\mathrm{OH})_{2} / \mathrm{NiOOH}$ electrode and the open-circuit voltage of the tested alloy electrode vs. $\mathrm{Hg} / \mathrm{HgO}$ reference electrode, respectively. The estimated specific power is 
inversely proportional to the measured internal resistance as shown in Figure 5. From Table 2, it is obvious that $\mathrm{KOH}$-etching (activation) is very effective to reduce the internal resistance in $\mathrm{C}_{15} \mathrm{AB}_{2}\left(\mathrm{C}_{\text {, }}\right.$ $-25 \%)$ and $\mathrm{Sm}$-based $\mathrm{A}_{2} \mathrm{~B}_{7}(\mathrm{~F},-19 \%)$ alloys. The reduction in the internal resistance is less significant in La-based $A_{2} B_{7}(E,-12 \%), C 14 A_{2}(B,-9 \%)$ and Mm-based Al-free $A_{2} B_{7}(G,-8 \%)$ alloys. Etching in $\mathrm{KOH}$ (activation) even increases the internal resistance of $\mathrm{AB}_{5}(\mathbf{A},+36 \%)$ and $\mathrm{BCC}-\mathrm{C} 14(\mathbf{D},+30 \%)$ alloys by large percentages. Three $A_{2} B_{7}$ alloys $(E, F$, and $G$ ) show lower $R$ than that of the standard $\mathrm{AB}_{5}(\mathrm{~A})$ after $\mathrm{KOH}$-etching. The as-prepared (no etch) $\mathrm{E}$ and $\mathrm{G}$ show even lower $R$ than that from $\mathrm{A}$ and have been used in the high-power design of $\mathrm{Ni} / \mathrm{MH}$ batteries [41,44]. Overall, $\mathrm{G}$ shows the lowest $R$ and the highest estimated specific power of $390 \mathrm{~W} \cdot \mathrm{kg}^{-1}$, which is considerably higher than that from the standard A $\left(317 \mathrm{~W} \cdot \mathrm{kg}^{-1}\right)$.

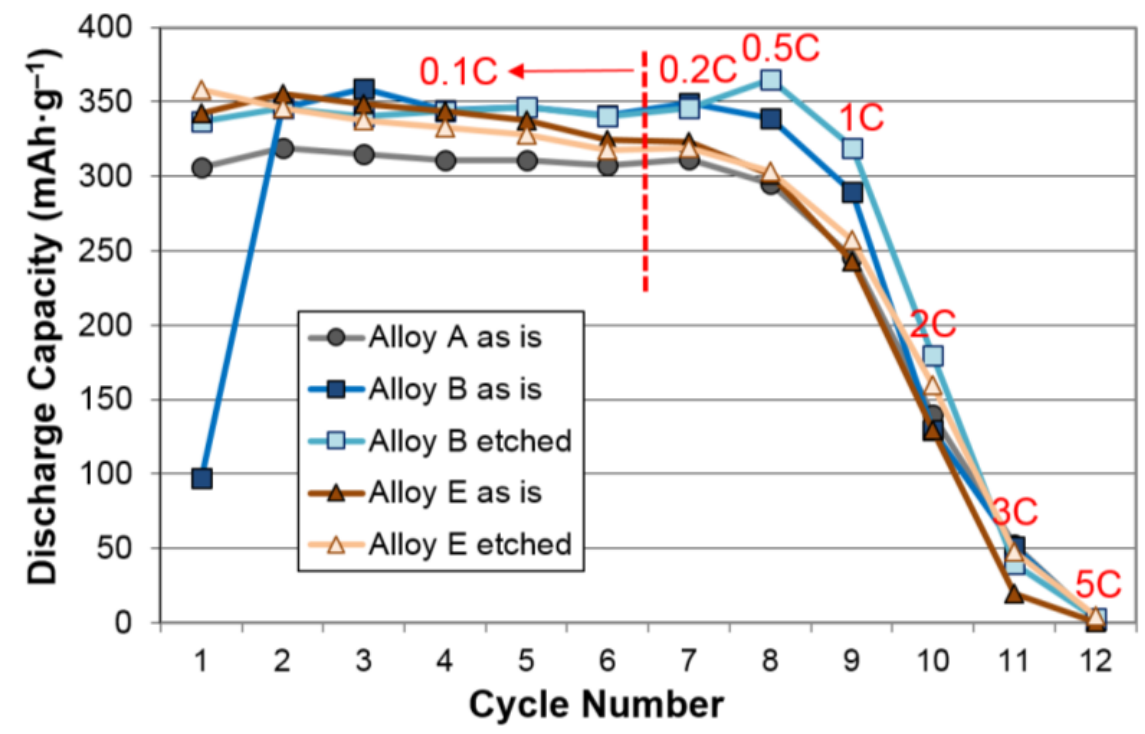

Figure 3. Examples of half-cell discharge capacities measured with $0.1 \mathrm{C}$ (cycle 1-6), $0.2 \mathrm{C}$ (cycle 7), 0.5 C (cycle 8), 1 C (cycle 9), 2 C (cycle 10), 3 C (cycle 11), and 5 C (cycle 12) rates from A (as-in only), $\mathbf{B}$ (both as-is and etched) and $\mathbf{E}$ (both as-is and etched).

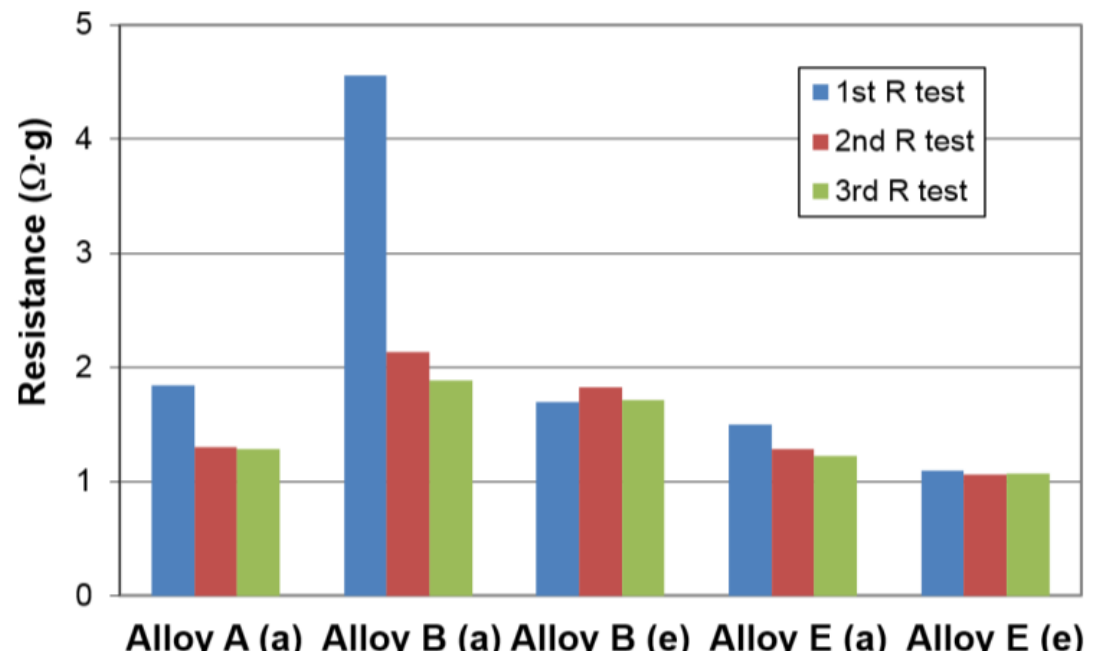

Figure 4. Examples of three internal resistance results from A (as-is only), B (both as-is and etched), and $\mathbf{E}$ (both as-is and etched). (a) and (e) in parentheses represent for as-is and etched. 
Table 2. Electrochemical discharge capacity measured at $50 \mathrm{~mA} \cdot \mathrm{g}^{-1}$, surface charge-transfer resistance $(R)$ from AC impedance measurement, and specific power density.

\begin{tabular}{|c|c|c|c|c|}
\hline Alloys & Treatment & Capacity $\left(\mathrm{mAh} \cdot \mathrm{g}^{-1}\right)$ & Resistance $(\Omega \cdot \mathrm{g})$ & Specific Power $\left(W \cdot \mathrm{kg}^{-1}\right)$ \\
\hline \multirow[b]{2}{*}{ A } & None & 321 & 1.28 & 317 \\
\hline & $\mathrm{KOH}$-etch & 321 & 1.74 & 238 \\
\hline \multirow[b]{2}{*}{ B } & None & 360 & $1.88^{*}$ & $228^{*}$ \\
\hline & $\mathrm{KOH}$-etch & 352 & $1.71^{*}$ & $261^{*}$ \\
\hline \multirow{2}{*}{ C } & None & 290 & $2.25^{*}$ & $192^{*}$ \\
\hline & $\mathrm{KOH}$-etch & 291 & $1.68^{*}$ & $256^{*}$ \\
\hline \multirow[b]{2}{*}{ D } & None & 390 & 1.80 & 235 \\
\hline & $\mathrm{KOH}$-etch & 349 & 2.34 & 181 \\
\hline \multirow{2}{*}{ E } & None & 356 & $1.22^{*}$ & $334^{*}$ \\
\hline & $\mathrm{KOH}$-etch & 358 & $1.07^{*}$ & $388^{*}$ \\
\hline \multirow{2}{*}{$\mathbf{F}$} & None & 300 & $1.42^{*}$ & $287^{*}$ \\
\hline & $\mathrm{KOH}$-etch & 304 & $1.15^{*}$ & $355^{*}$ \\
\hline \multirow{2}{*}{ G } & None & 353 & $1.13^{*}$ & $347^{*}$ \\
\hline & $\mathrm{KOH}$-etch & 353 & $1.04^{*}$ & $390^{*}$ \\
\hline \multirow[b]{2}{*}{$\mathbf{H}$} & None & 345 & 1.86 & 218 \\
\hline & $\mathrm{KOH}$-etch & 320 & 2.04 & 202 \\
\hline
\end{tabular}

Note: * The reduced $R$ from the $\mathrm{KOH}$-etch treatment.

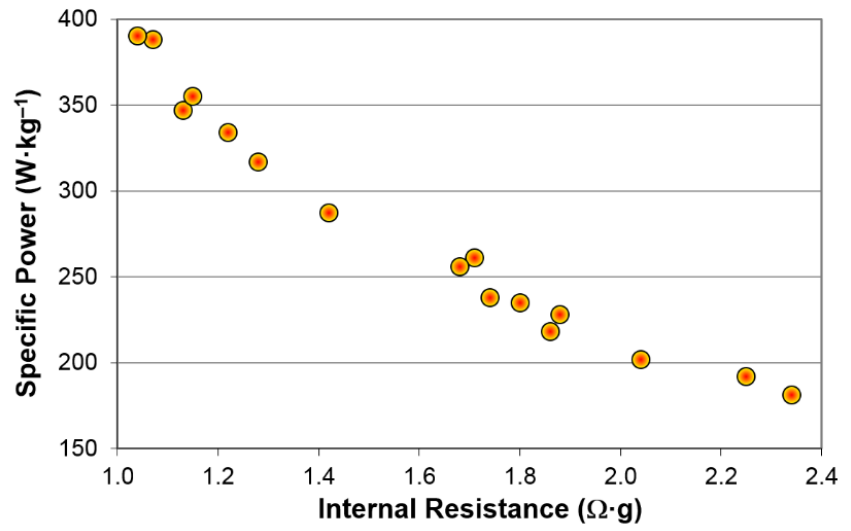

Figure 5. Plot of the calculated specific power vs. internal resistance for as-is and etched $\mathbf{A}-\mathbf{H}$.

The superiority of $\mathbf{E}$ vs. A in the high-rate performance has been verified by room-temperature AC impedance measured at different frequencies as shown in Figure 6. The radius of the semi-circle represents the surface charge-transfer resistance and shows the trend of as-is $\mathbf{A}>$ as-is $\mathbf{E}>$ etched $\mathbf{E}$, which is in total agreement with the internal resistance measurement.

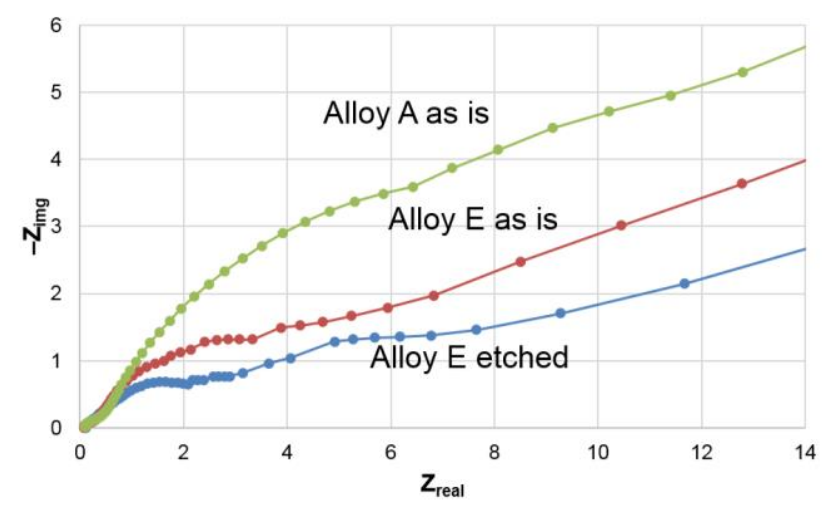

Figure 6. Cole-Cole plots obtained from room temperature alternative current (AC) impedance measurements of $\mathbf{A}$ (as-is only) and $\mathbf{E}$ (both as-is and etched). 
The HRD capability of MH alloy was associated with the metallic nickel clusters embedded in its surface oxide after activation $[45,46]$. The saturated magnetic susceptibility $\left(M_{\mathrm{S}}\right)$ obtained from the magnetic susceptibility measurement shows clear correlation to the HRD of a series of $A_{2} B_{7} M H$ alloys [13]. However, we also reported that some MH alloys with HRD were more related to the structure of the metal/oxide interface $[47,48]$. Therefore, it is interesting to compare the internal resistance of the etched alloy with the $M_{S}$ values reported in the literature (Table 1). The resulting plot is shown in Figure 7 (red dots) and does not reveal any clear correlation. The difference in $R$ before and after etching is also plotted in the same figure (triangles) and no clear trend can be seen. We conclude that an $M_{\mathrm{S}}$ estimation of surface catalytic ability can be used only in the comparison of a series of $\mathrm{MH}$ alloys with a similar composition/structure and cannot be elaborated freely among various alloy systems.

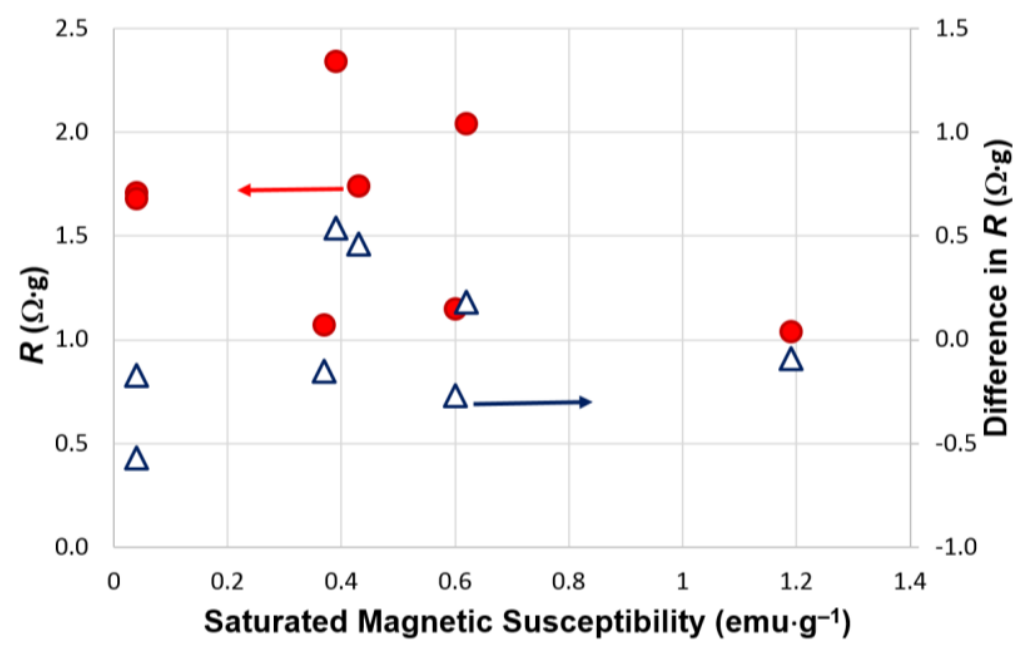

Figure 7. Plots of the internal resistance ( $R$ measured from the annealed alloys and the difference in $R$ before and after annealing (triangle) vs. the saturated magnetic susceptibility $\left(M_{\mathrm{S}}\right)$ (red dots)).

\subsection{Microsnalysis of the Activated Surface}

SEM micrographs taken from the surfaces of etched alloys are shown in Figure 8. While the surfaces of RE-based $\mathrm{AB}_{5}(\mathrm{~A})$ and $\mathrm{A}_{2} \mathrm{~B}_{7}(\mathrm{E}-\mathrm{H})$ alloys are covered with $\mathrm{RE}(\mathrm{OH})_{3}$ needles, those from TM-based $\mathrm{AB}_{2}$ (B and C) and BCC-C14 (D) are modified by patches of $\mathrm{ZrO}_{2}$. Needles from $\mathrm{La}(\mathrm{OH})_{3}$ are smaller compared to hydroxides from other RE elements [24]. The microstructures of RE- and TM-based MH alloys were studied by transmission electron microscope before and can be summarized as a $50 \mathrm{~nm}$ buffer oxide (amorphous) and a $100 \mathrm{~nm}$ surface oxide with $\mathrm{Ni}$-inclusion with $\mathrm{RE}(\mathrm{OH})_{3}$ needles on top in the former and a $100 \mathrm{~nm}$ buffer oxide layer and a $200 \mathrm{~nm}$ surface oxide with $\mathrm{Ni}$-inclusion with patches of $\mathrm{ZrO}_{2}$ on top in the latter [24]. While the RE in $\mathrm{AB}_{5}$ and $\mathrm{A}_{2} \mathrm{~B}_{7}$ alloys formed an impeccable passive surface oxide when reacting with hot $\mathrm{KOH}$, the TM just leaches out into electrolyte. The weight comparison of three $\mathbf{B}\left(\mathrm{AB}_{2}\right)$ and three $\mathbf{E}\left(\mathrm{A}_{2} \mathrm{~B}_{7}\right)$ electrodes before and after $\mathrm{KOH}$-etching (dried in vacuum over for $24 \mathrm{~h}$ ) were conducted and results are listed in Table 3 and plotted in Figure 9. The average weight loss (gain) for B and E (MH powder only) are $-2.2 \%$ and $+1.0 \%$. The leached-out species were further analyzed by examining the composition of the alkaline solution after the etching experiment with ICP and results are summarized in Table 4. In the solutions with RE-based alloys, only $\mathrm{Al}(\mathbf{A}, \mathbf{F}$, and $\mathbf{H})$ and a very small amount of $\mathrm{Mg}(\mathbf{E}, \mathbf{F}$, and $\mathbf{G})$ are detected. In the TM-based alloys (B-D), larger concentrations of $\mathrm{Ti}, \mathrm{V}$, and $\mathrm{Zr}$ are found. The Ni-concentrations in the solutions from TM-based alloys are much higher than those from the RE-based one, while the former have smaller Ni-content in their compositions. This is additional evidence showing that when the TM-based alloys were attached by hot $\mathrm{KOH}$ they went through a preferential leach-out and the RE-based alloys formed a passive hydroxide layer under the same situation. 
To confirm the results from SEM and ICP analysis, XRD was performed, and the resulting patterns obtained before and after $\mathrm{KOH}$-etch for each alloy in this study are plotted in Figure 10. All RE-based $\mathrm{MH}$ alloys (A, E-H) show peaks of $\mathrm{RE}(\mathrm{OH})_{3}$ after etching. Only etched $\mathbf{B}$ shows $\mathrm{ZrO}_{2}$ phase, and both $\mathrm{AB}_{2}$ alloys (B and $\mathbf{C}$ ) contain metallic $\mathrm{Ni}$ as a product of corrosion after etching. $D$ exhibited a small portion of partially hydride ( $\alpha$-phase) formed by storing the hydrogen generated from the high level of oxidation of TM (mainly V [11]). The metal-hydrogen bond of the product from the initial hydrogenation is very strong, as seen from the large portion of low-pressure irreversible hydrogen storage in D (PCT in Figure 1). The XRD analysis results indicate that the leaching-out (corrosion) of the alloy surface by hot $\mathrm{KOH}$ is in the order of $\mathbf{D}>\mathbf{C}>\mathbf{B}>$ the rest.
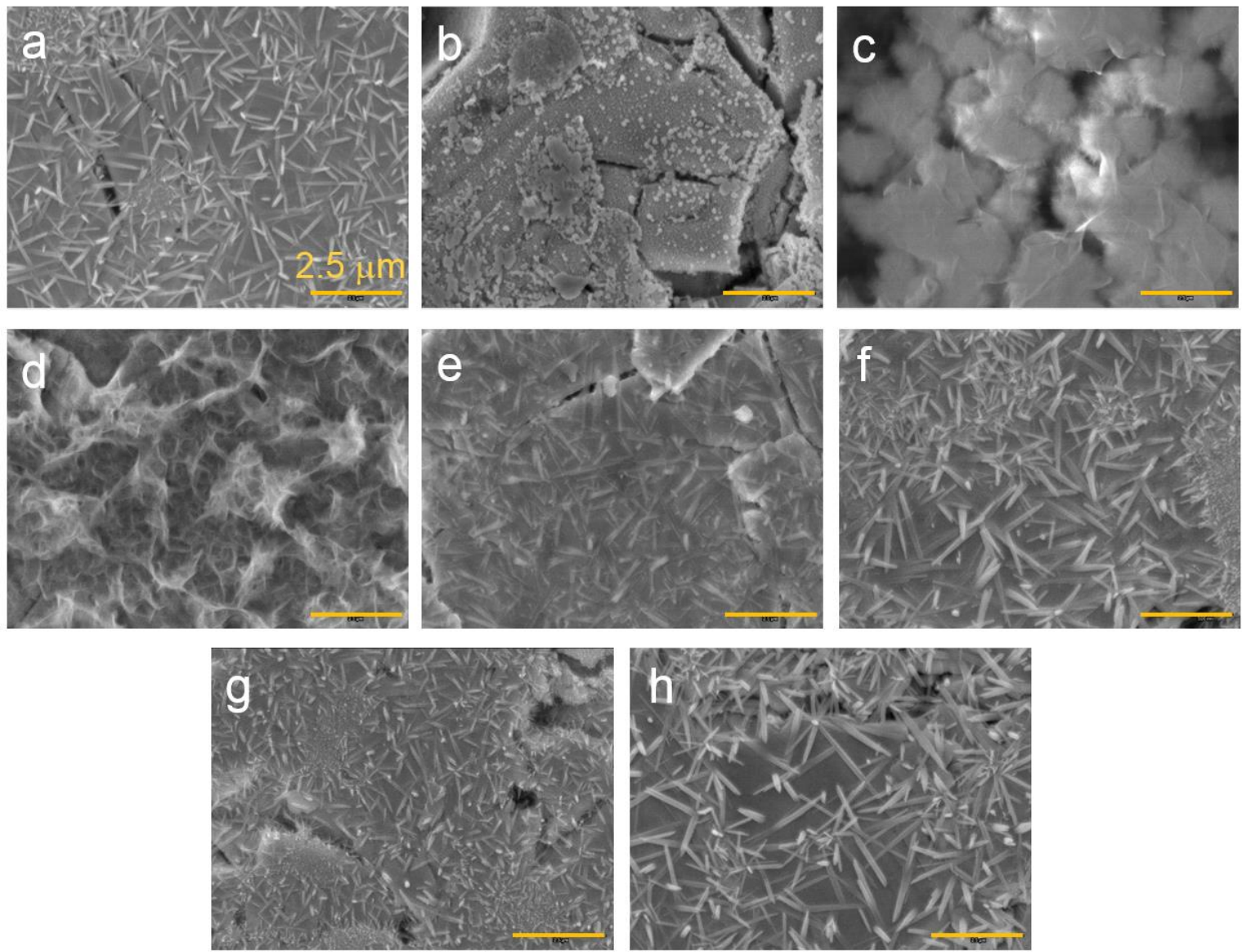

Figure 8. Scanning electron microscopy (SEM) micrographs from the etched alloys (a) A, (b) B, (c) C, (d) D, (e) E, (f) F, (g) G and (h) H. The bar at the lower right corner in each micrograph represents $2.5 \mu \mathrm{m}$.

Table 3. Measurement of weight change before and after $\mathrm{KOH}$-etch for $\mathbf{A}$ and $\mathbf{B}$. All numbers are in $\mathrm{mg}$.

\begin{tabular}{ccccc}
\hline Sample \# & Substrate Weight & Electrode Wright Before & Electrode Weight After & Weight Difference \\
\hline B 1 & 192.8 & 262.3 & 260.8 & -1.5 \\
B 2 & 182.7 & 257.4 & 255.7 & -1.7 \\
B 3 & 178.4 & 252.0 & 250.5 & -1.5 \\
E 1 & 199.5 & 279.6 & 280.3 & 0.7 \\
E 2 & 181.3 & 278.7 & 279.8 & 1.1 \\
E 3 & 186.4 & 289.0 & 290.1 & 1.1 \\
\hline
\end{tabular}




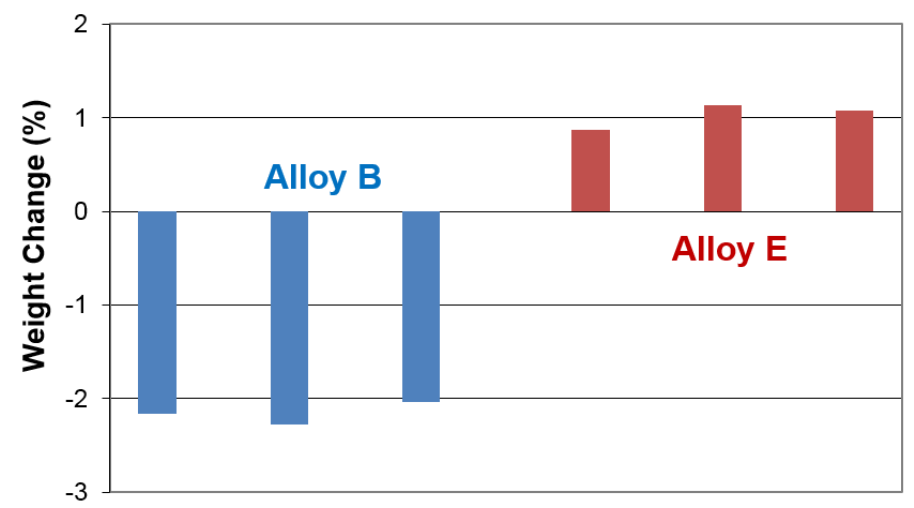

Figure 9. Weight changes after $\mathrm{KOH}$-etching for three electrodes from $\mathbf{B}$ (left) and three from $\mathbf{E}$ (right).

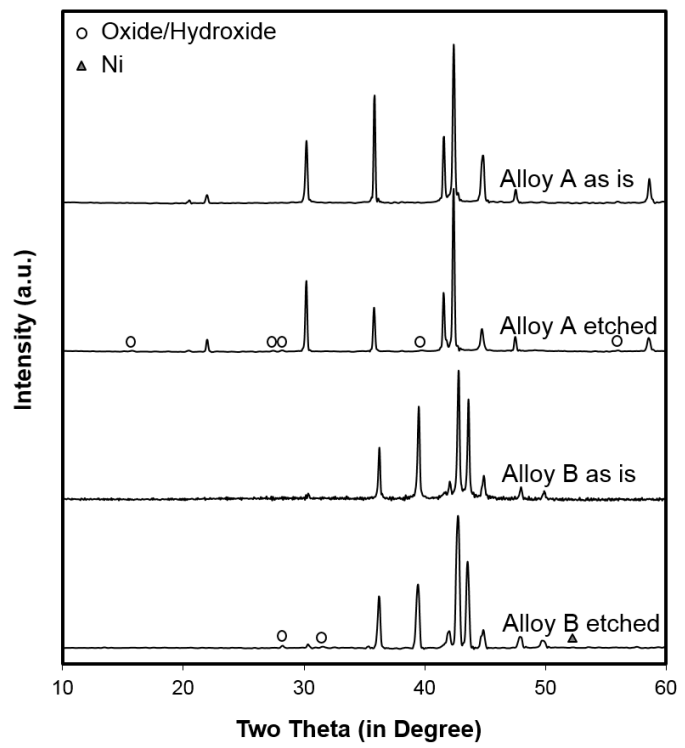

(a)

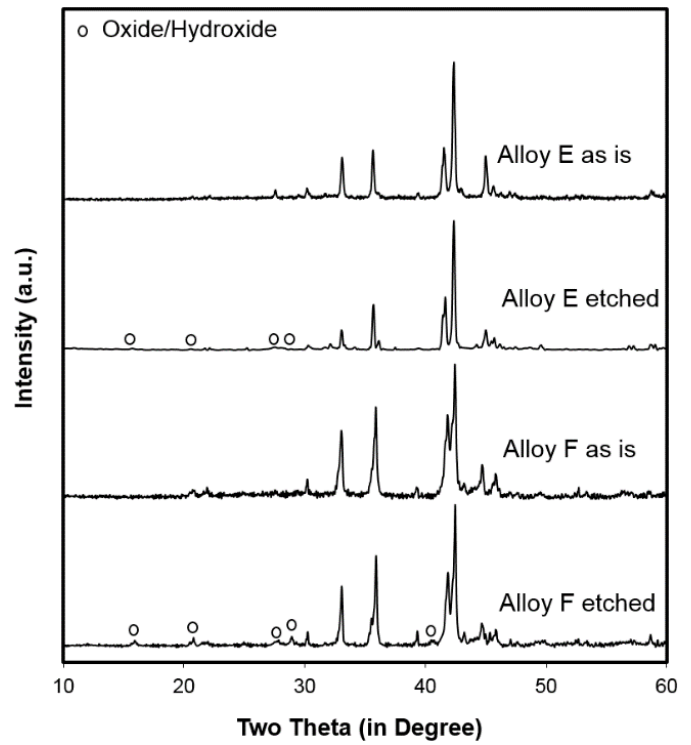

(c)

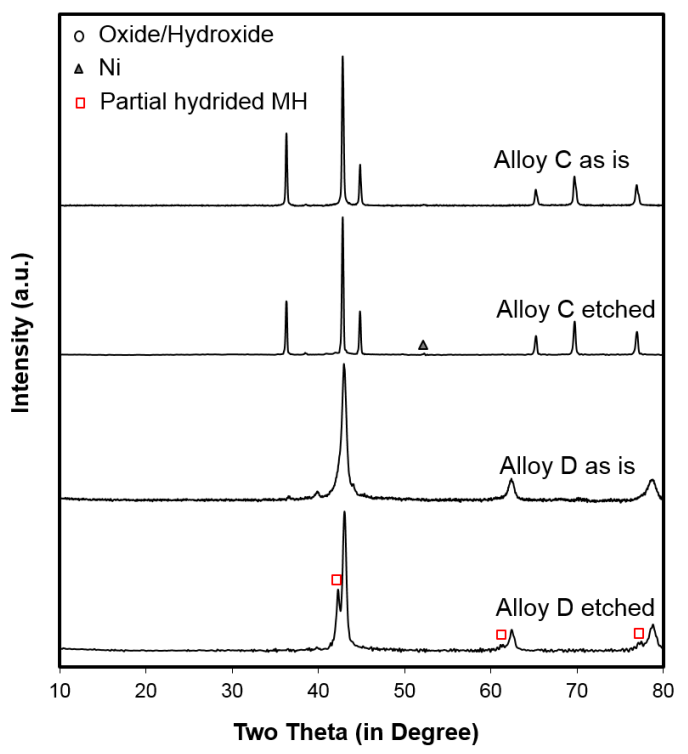

(b)

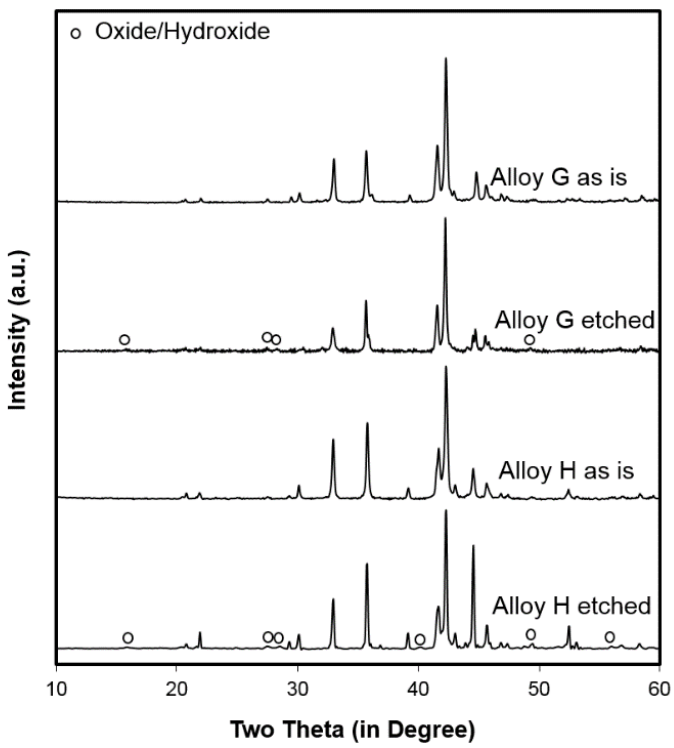

(d)

Figure 10. X-ray diffractometer (XRD) patterns using $\mathrm{Cu}-\mathrm{K}_{\alpha}$ as the radiation source for alloys (a) A, B, (b) C, D, (c) E, F and (d) G, H before and after KOH-etching. 
Table 4. ICP results (in unit of ppm) from the solutions after etching experiment. N.D. and LLD denote non-detectable (below LLD) and lowest limit of detection, respectively.

\begin{tabular}{cccccccccc}
\hline Alloy & A & B & C & D & E & F & G & H & LLD \\
\hline $\mathrm{Al}$ & 58 & 1.6 & N.D. & 29 & N.D. & 78 & N.D. & 20 & 0.012 \\
$\mathrm{Co}$ & N.D. & 0.1 & N.D. & 1.0 & N.D. & N.D. & 1.2 & N.D. & 0.004 \\
$\mathrm{Cr}$ & N.D. & 4.3 & N.D. & 48 & N.D. & N.D. & N.D. & N.D. & 0.054 \\
$\mathrm{Fe}$ & N.D. & N.D. & 1.0 & N.D. & N.D. & N.D. & N.D. & N.D. & 0.002 \\
$\mathrm{Mg}$ & N.D. & N.D. & N.D. & N.D. & 0.05 & 0.3 & 0.5 & N.D. & 0.001 \\
$\mathrm{Mn}$ & N.D. & 2.0 & 0.1 & 8.0 & N.D. & N.D. & N.D. & N.D. & 0.001 \\
$\mathrm{Ni}$ & N.D. & 6.0 & 0.3 & 5.0 & N.D. & N.D. & N.D. & N.D. & 0.001 \\
$\mathrm{Ti}$ & N.D. & 150 & 7 & 416 & N.D. & N.D. & N.D. & N.D. & 0.004 \\
$\mathrm{~V}$ & N.D. & 125 & 92 & 988 & N.D. & N.D. & N.D. & N.D. & 0.013 \\
$\mathrm{Zr}$ & N.D. & 495 & 518 & 309 & N.D. & N.D. & N.D. & N.D. & 0.002 \\
\hline
\end{tabular}

\section{Conclusions}

Combining the electrochemical testing results and microstructure analysis, we have the following findings: The improvement in the high-rate capability (reduction in $R$ ) by $\mathrm{KOH}$-etch is the most prominent in $\mathrm{C}_{15} \mathrm{AB}_{2}(\mathrm{C})$ with a small La-content, followed by two $\mathrm{A}_{2} \mathrm{~B}_{7}$ alloys (E and $\left.\mathbf{F}\right)$ with $\mathrm{Mg}$, and then $\mathrm{C}_{14} \mathrm{AB}_{2}(\mathrm{~A})$ and an $\mathrm{A}_{2} \mathrm{~B}_{7}$ with $\mathrm{Mg}$ and no $\mathrm{Al}(\mathrm{G})$. The $\mathrm{KOH}$-etch deteriorates the high-rate performance (increase in $R$ ) in the standard $\mathrm{Mg}_{\text {-free }} \mathrm{AB}_{5}(\mathrm{~A})$ and V-rich BCC-C14 (D) alloys, whereas Mg-content in $\mathrm{A}_{2} \mathrm{~B}_{7} \mathrm{MH}$ alloys responds well with the $\mathrm{KOH}$-etch and La also helps the decrease in surface charge-transfer resistance by etching. BCC phase in a multiple phase alloy is more robust against the $\mathrm{KOH}$ corrosion [49] and is inert in the electrochemical environment [50-52]. Etching at a high temperature will increase the density of BCC phase on the surface and impede the electrochemical reaction, which explains the severe degradation in high-power performance of alloy $\mathbf{D}$ after $\mathrm{KOH}$-etch.

Acknowledgments: The authors would like to thank the following individuals from BASF-Ovonic for their help: Taihei Ouchi, Jean Nei, Shuan Chang, Su Cronogue, Baoquan Huang, William Mays, Diana F. Wong, David Pawlik, Allen Chan, and Ryan J. Blankenship.

Author Contributions: Tiejun Meng performed the experiment and analyzed results. Kwo-Hsiung Young contributed to data analysis and manuscript preparation. Chaolan $\mathrm{Hu}$ and Benjamin Reichman provided the $\mathrm{KOH}$-etching recipe and helped in $\mathrm{AC}$ impedance measurement and data interpretation.

Conflicts of Interest: The authors declare no conflict of interest.

\section{Abbreviations}

The following abbreviations are used in this manuscript:

$\begin{array}{ll}\text { MH } & \text { Metal hydride } \\ \text { IMC } & \text { Intermetallic compound } \\ \text { Ni/MH } & \text { Nickel/metal hydride } \\ \text { BCC } & \text { Body-centered-cubic } \\ \text { TM } & \text { Transition metal } \\ \text { RE } & \text { Rare earth } \\ \text { HRD } & \text { High-rate dischargeability } \\ \text { VIM } & \text { Vacuum induction melting } \\ \text { AM } & \text { Arc melting } \\ \text { PCT } & \text { Pressure-concentration-temperature } \\ \text { ICP-OES } & \text { Inductively coupled plasma-optical emission } \\ & \text { spectrometer } \\ \text { XRD } & \text { X-ray diffractometer } \\ \text { SEM } & \text { Scanning electron microscope } \\ \text { SOC } & \text { State of charge }\end{array}$




$\begin{array}{ll}M_{\mathrm{S}} & \text { Saturated magnetic susceptibility } \\ \mathrm{AC} & \text { Alternative current } \\ R & \text { Internal resistance } \\ P & \text { Specific power } \\ V_{\mathrm{oc}} & \text { Open-circuit voltage }\end{array}$

\section{References}

1. Young, K. Metal Hydride. In Elsevier Reference Module in Chemistry, Molecular Sciences and Chemical Engineering; Reedijk, J., Ed.; Elsevier: Waltham, MA, USA, 2013.

2. Goo, N.H.; Woo, J.H.; Lee, K.S. Mechanism of Rapid Degradation of Nanostructured $\mathrm{Mg}_{2} \mathrm{Ni}$ Hydrogen Storage Alloy Electrode Synthesized by Mechanical Alloying and the Effect of Mechanically Coating with Nickel. J. Alloys Compd. 1999, 288, 286-293. [CrossRef]

3. Zhang, Q.A.; Lei, Y.Q.; Wang, C.S.; Wang, F.S.; Wang, Q.D. Structure of the Secondary Phase and Its Effects on Hydrogen-storage Properties in a $\mathrm{Ti}_{0.7} \mathrm{Zr}_{0.2} \mathrm{~V}_{0.1} \mathrm{Ni}$ Alloy. J. Power Sour. 1998, 75, 288-291. [CrossRef]

4. Nei, J.; Young, K. Gaseous Phase and Electrochemical Hydrogen Storage Properties of $\mathrm{Ti}_{50} \mathrm{Zr}_{1} \mathrm{Ni}_{44} \mathrm{X}_{5}$ $(\mathrm{X}=\mathrm{Ni}, \mathrm{Cr}, \mathrm{Mn}, \mathrm{Fe}, \mathrm{Co}$, or $\mathrm{Cu})$ for Nickel Metal hydride Battery Applications. Batteries 2016, 2, 24. [CrossRef]

5. Züttel, A.; Meli, F.; Schlapbach, L. Electrochemical and Surface Properties of $\mathrm{Zr}\left(\mathrm{V}_{x} \mathrm{Ni}_{1-x}\right)_{2}$ Alloys as Hydrogen-absorbing Electrodes in Alkaline Electrolyte. J. Alloys Compd. 1994, 203, 235-241.

6. Liao, B.; Lei, Y.Q.; Chen, L.X.; Lu, G.L.; Pan, H.G.; Wang, Q.D. A Study on the Structure and Electrochemical Properties of $\mathrm{La}_{2} \mathrm{Mg}\left(\mathrm{Ni}_{0.95} \mathrm{M}_{0.05}\right)_{9}(\mathrm{M}=\mathrm{Co}, \mathrm{Mn}, \mathrm{Fe}, \mathrm{Al}, \mathrm{Cu}, \mathrm{Sn})$ Hydrogen Storage Electrode Alloys. J. Alloys Compd. 2004, 376, 186-195. [CrossRef]

7. Yasuoka, S.; Magari, Y.; Murata, T.; Tanaka, T.; Ishida, J.; Nakamura, H.; Nohma, T.; Kihara, M.; Baba, Y.; Teraoka, H. Development of High-capacity Nickel-metal Hydride Batteries Using Superlattice Hydrogen-Absorbing Alloys. J. Power Sour. 2006, 156, 662-666. [CrossRef]

8. Zhao, Y.; Zhang, L.; Ding, Y.; Cao, J.; Jia, Z.; Ma, C.; Li, Y.; Han, S. Comparative Study on the Capacity Degradation Behavior of $\operatorname{Pr}_{5} \mathrm{Co}_{19}$-type Single-phase $\operatorname{Pr}_{4} \mathrm{MgNi}_{19}$ and $\mathrm{La}_{4} \mathrm{MgNi}_{19}$ Alloys. J. Alloys Compd. 2017, 694, 1089-1097. [CrossRef]

9. Willems, J.J.G.; Buschow, K.H.J. From Permanent Magnets to Rechargeable Hydride Electrodes. J. Less Common Met. 1987, 129, 13-30. [CrossRef]

10. Young, K.; Ouchi, T.; Huang, B.; Nei, J. Structure, Hydrogen Storage, and Electrochemical Properties of Body-centered-cubic $\mathrm{Ti}_{40} \mathrm{~V}_{30} \mathrm{Cr}_{15} \mathrm{Mn}_{13} \mathrm{X}_{2}$ alloys (X=B, Si, Mn, Ni, Zr, Nb, Mo, and La). Batteries 2015, 1, 74-90. [CrossRef]

11. Young, K.; Nei, J.; Wong, D.F.; Wang, L. Structural, Hydrogen Storage, and Electrochemical Properties of Laves Phase-related Body-centered-cubic Solid Solution Metal Hydride Alloys. Int. J. Hydrog. Energy 2014, 39, 21489-21499. [CrossRef]

12. Young, K.; Ng, K.Y.S.; Bendersky, L.A. A Technical Report of the Robust Affordable Next Generation Energy Storage System-BASF program. Batteries 2016, 2, 2. [CrossRef]

13. Young, K.; Ouchi, T.; Huang, B.; Chao, B.; Fetcenko, M.A.; Bendersky, L.A.; Wang, K.; Chiu, C. The Correlation of $\mathrm{C} 14 / \mathrm{C} 15$ Phase Abundance and Electrochemical Properties in the $\mathrm{AB}_{2}$ Alloys. J. Alloys Compd. 2010, 506, 841-848. [CrossRef]

14. Young, K.; Nei, J. The Current Status of Hydrogen Storage Alloy Development for Electrochemical Applications. Materials 2013, 6, 4574-4608. [CrossRef] [PubMed]

15. Young, K.; Chang, S.; Lin, X. C14 Laves Phase Metal Hydride Alloys for Ni/MH Batteries Applications. Batteries 2017, 3, 27. [CrossRef]

16. Schlapbach, L.; Seiler, A.; Siegmann, H.C.; Waldkirch, T.V.; Zücher, P.; Brundle, C.R. Self Restoring of the Active Surface in $\mathrm{LaNi}_{5}$. Int. J. Hydrog. Energy 1979, 4, 21-28. [CrossRef]

17. Fetcenko, M.A.; Young, K.; Ovshinsky, S.R.; Reichman, B.; Koch, J.; Mays, W. Modified Electrochemical Hydrogen Storage Alloy Having Increased Capacity, Rate Capability and Catalytic Activity. US Patent 6,740,448, 25 May 2004.

18. Meli, F.; Schlapbach, L. Surface Analysis of $\mathrm{AB}_{5}$-type electrodes. J. Less Common Met. 1991, 172, $1252-1259$. [CrossRef] 
19. Broom, D.P.; Kemali, M.; Ross, D.K. Magnetic Properties of Commercial Metal Hydride Battery Materials. J. Alloys Compd. 1999, 255, 293-295. [CrossRef]

20. Yu, B.; Chen, L.; Wen, M.F.; Tong, M.; Chen, D.M.; Tian, Y.W.; Zhai, Y.C. Surface Modification of $\mathrm{AB}_{2}$ and $\mathrm{AB}_{5}$ Hydrogen Storage Alloy Electrodes by the Hot-charging Treatment. J. Mater. Sci. Technol. 2001, 17, $247-251$.

21. Shen, Y.; Peng, F.; Kontos, S.; Noréus, D. Improved NiMH Performance by a Surface Treatment that Creates Magnetic Ni-clusters. Int. J. Hydrog. Energy 2016, 41, 9933-9938. [CrossRef]

22. Tan, S.; Shen, Y.; Şahin, E.Q.; Noréus, D.; Öztürk, T. Activation Behavior of an $\mathrm{AB}_{2}$ Type Metal Hydride Alloy for NiMH Batteries. Int. J. Hydrog. Energy 2016, 41, 9948-9953. [CrossRef]

23. Ye, Z.; Noréus, D. Metal hydride electrodes: The Importance of Surface Area. J. Alloys Compd. 2016, 664, 59-64. [CrossRef]

24. Young, K.; Chao, B.; Liu, Y.; Nei, J. Microstructures of the Oxides on the Activated $\mathrm{AB}_{2}$ and $\mathrm{AB}_{5} \mathrm{Metal}$ Hydride Alloys Surface. J. Alloys Compd. 2014, 606, 97-104. [CrossRef]

25. Chang, S.; Young, K.; Ouchi, T.; Meng, T.; Nei, J.; Wu, X. Studies on Incorporation of Mg in Zr-based $\mathrm{AB}_{2}$ Metal Hydride Alloys. Batteries 2016, 2, 11. [CrossRef]

26. Young, K.; Wong, D.F.; Nei, J. Effects of Vanadium/nickel Contents in Laves Phase-related Body-centered-cubic Solid Solution Metal Hydride Alloys. Batteries 2015, 1, 34-53. [CrossRef]

27. Teraoka, H. Development of Low Self-Discharge Nickel-Metal Hydride Battery. Available online: http: / / www.scribd.com/doc/9704685/Teraoka-Article-En (accessed on 9 April 2016).

28. Kai, T.; Ishida, J.; Yasuoka, S.; Takeno, K. The Effect of Nickel-Metal Hydride Battery's Characteristics with Structure of the Alloy. In Proceedings of the 54th Battery Symposium in Japan, Osaka, Japan, 7-9 October 2013; p. 210.

29. Liu, F.J.; Kitayama, K.; Suda, S. La and Ce-incorporation Effects on the Surface Properties of the Fluorinated $(\mathrm{Ti}, \mathrm{Xr})(\mathrm{Mn}, \mathrm{Cr}, \mathrm{Ci})_{2}$ Hydriding Alloys. Vacuum 1996, 47, 903-906. [CrossRef]

30. Kim, S.; Lee, J. Activation behaviour of $\mathrm{ZrCrNiM}_{0.05}$ metal hydride electrode $(\mathrm{M}=\mathrm{La}, \mathrm{Mm}$ (misch metal), Nd). J. Alloys Compd. 1992, 185, L1-L4. [CrossRef]

31. Park, H.Y.; Chang, I.; Cho, W.I.; Cho, B.W.; Jang, H.; Lee, S.R.; Yun, K.S. Electrode Characteristics of the Cr and La Doped $\mathrm{AB}_{2}$-type Hydrogen Storage Alloys. Int. J. Hydrog. Energy 2001, 26, 949-955. [CrossRef]

32. Liu, F.J.; Sandrock, G.; Suda, S. Surface and Metallographic Microstructure of the La-added $\mathrm{AB}_{2}$ Compound (Ti, Zr)(Mn, Cr, Ni) 2 . J. Alloys Compd. 1995, 231, 392-396. [CrossRef]

33. Sun, D.; Latroche, M.; Percheron-Guégan, A. Effects of Lanthanum or Cerium on the Equilibrium of $\mathrm{ZrNi}_{1.2} \mathrm{Mn}_{0.6} \mathrm{~V}_{0.2} \mathrm{Cr}_{0.1}$ and Its Related Hydrogenation Properties. J. Alloys Compd. 1997, 248, 215-219.

34. Yang, X.G.; Lei, Y.Q.; Shu, K.Y.; Lin, G.F.; Zhang, Q.A.; Zhang, W.K.; Zhang, X.B.; Lu, G.L.; Wang, Q.D. Contribution of Rare-earths to Activation Property of Zr-based Hydride Electrode. J. Alloys Compd. 1999, 293, 632-636. [CrossRef]

35. Sun, J.C.; Li, S.; Ji, S.J. The Effects of the Substitution of Ti and La for $\mathrm{Zr}$ in $\mathrm{ZrMn}_{0.7} \mathrm{~V}_{0.2} \mathrm{Co}_{0.1} \mathrm{Ni}_{1.2}$ Hydrogen Storage Alloys on the Phase Structure and Electrochemical Properties. J. Alloys Compd. 2007, 446, 630-634.

36. Chen, W.X. Effects of Addition of Rare-earth Element on Electrochemical Characteristics of $\mathrm{ZrNi}_{1.1} \mathrm{Mn}_{0.5} \mathrm{~V}_{0.3}$ $\mathrm{Cr}_{0.1}$ Hydrogen Storage Alloy Electrodes. J. Alloys Compd. 2001, 319, 119-123.

37. Young, K.; Ouchi, T.; Huang, B.; Reichman, B.; Fetcenko, M.A. Effect of Molybdenum Content on Structural, Gaseous Storage, and Electrochemical Properties of C14-predominant $\mathrm{AB}_{2}$ Metal Hydride Alloys. J. Power Sour. 2011, 196, 8815-8821. [CrossRef]

38. Young, K.; Nei, J.; Wan, C.; Denys, R.V.; Yartys, V.A. Comparison of C14- and C15-predominated AB 2 Metal Hydride Alloys for Electrochemical Applications. Batteries 2017, 3, 22. [CrossRef]

39. Young, K.; Ouchi, T.; Meng, T.; Wong, D.F. Studies on the Synergetic Effects in Multi-phase Metal Hydride Alloys. Batteries 2016, 2, 15. [CrossRef]

40. Young, K.; Ouchi, T.; Nei, J.; Koch, J.M.; Lien, Y. Comparison among constituent phases in superlattice metal hydride alloys for battery applications. Batteries 2017. submitted.

41. Koch, J.M.; Young, K.; Nei, J.; Hu, C.; Reichman, B. Performance comparison between AB $_{5}$ and superlattice metal hydride alloys in sealed cells. Batteries 2017. submitted.

42. Wang, L.; Young, K.; Meng, T.; Ouchi, T.; Yasuoka, S. Partial Substitution of Cobalt for Nickel in Mixed Rare Earth Metal Based Superlattice Hydrogen Absorbing Alloy-Part 1 Structural, Hydrogen Storage and Electrochemical Properties. J. Alloys Compd. 2016, 660, 407-415. [CrossRef] 
43. Young, K.; Yasuoka, S. Past, present, and future of metal hydride alloys in nickel-metal hydride batteries. In Proceedings of the 14th International Symposium on Metal-Hydrogen Systems, Manchester, UK, 21-25 July 2014.

44. Zhou, X.; Young, K.; West, J.; Regalado, J.; Cherisol, K. Degradation Mechanisms of High-energy Bipolar Nickel Metal Hydride Battery with $\mathrm{AB}_{5}$ and $\mathrm{A}_{2} \mathrm{~B}_{7}$ Alloys. J. Alloys Compd. 2013, 580, S373-S377. [CrossRef]

45. Stucki, F.; Schlapbach, L. Magnetic Properties of $\mathrm{LaNi}_{5}, \mathrm{FeTi}, \mathrm{Mg}_{2} \mathrm{Ni}$ and Their Hydrides. J. Less Common Met. 1980, 74, 143-151. [CrossRef]

46. Schlapbach, L.; Stucki, F.; Seiler, A.; Siegmann, H.C. Magnetism and Hydrogen Storage in LaNi ${ }_{5}, \mathrm{FeTi}_{\text {and }}$ $\mathrm{Mg}_{2}$ Ni. J. Magn. Magn. Mater. 1980, 15-18, 1271-1272. [CrossRef]

47. Young, K.; Chao, B.; Nei, J. Microstructures of the Activated Si-containing $\mathrm{AB}_{2}$ Metal Hydride Alloy Surface by Transmission Electron Microscope. Batteries 2016, 2, 4. [CrossRef]

48. Young, K.; Chao, B.; Pawlik, D.; Shen, H.T. Transmission Electron Microscope Studies in the Surface Oxide on the La-containing $\mathrm{AB}_{2}$ Metal Hydride Alloy. J. Alloys Compd. 2016, 672, 356-365. [CrossRef]

49. Young, K.H.; Fetcenko, M.A.; Ovshinsky, S.R.; Ouchi, T.; Reichman, B.; Mays, W.C. Improved Surface Catalysis of Zr-based Laves Phase Alloys for NiMH Batteries. In Hydrogen at Surface and Interfaces; Jerkiewicz, G., Feliu, J.M., Popov, B.N., Eds.; Electrochemical Society: Pennington, NJ, USA, 2000.

50. Lee, H.; Chourashiya, M.G.; Park, C.; Park, C. Hydrogen Storage and Electrochemical Properties of the Ti $i_{0.32}$ $\mathrm{Cr}_{0.43-x-y} \mathrm{~V}_{0.25} \mathrm{Fe}_{x} \mathrm{Mn}_{y}(x=0-0.055, y=0-0.080)$ Alloys and Their Composites with $\mathrm{MmNi}_{3.99} \mathrm{Al}_{0.29} \mathrm{Mn}_{0.3}$ $\mathrm{Co}_{0.6}$ Alloy. J. Alloys Compd. 2013, 566, 37-42. [CrossRef]

51. Inoue, H.; Arai, S.; Iwakura, C. Crystallographic and Electrochemical Characterization of $\mathrm{TiV}_{4-x} \mathrm{Ni}_{x}$ Alloys for Nickel-metal Hydride Batteries. Electrochim. Acta 1996, 41, 937-939. [CrossRef]

52. Yu, X.B.; Wu, Z.; Xia, B.J.; Xu, N.X. A Ti-V-based bcc Phase Alloy for Use as Metal Hydride Electrode with High Discharge Capacity. J. Chem. Phys. 2004, 121, 987-990. [CrossRef] [PubMed]

(C) 2017 by the authors. Licensee MDPI, Basel, Switzerland. This article is an open access article distributed under the terms and conditions of the Creative Commons Attribution (CC BY) license (http:/ / creativecommons.org/licenses/by/4.0/). 